\title{
PELATIHAN PENYUSUNAN LAPORAN KEUANGAN BERDASARKAN SAK EMKM PADA UMKM PANGAN DI KOTA BANJARMASIN
}

\author{
Hj. Nurul Qalbiah ${ }^{1}$, Hj. Nurul Mukhlisah ${ }^{2}, J_{\text {ulkawait }}^{3}$, Widya Ais Sahla \\ Jurusan Akuntansi Politeknik Negeri Banjarmasin ${ }^{1234}$ \\ nurul_qalbiah@poliban.ac.id ${ }^{l}$
}

\begin{abstract}
The number of SMEs in Banjarmasin in 2016 reached 33,781 units and in 2017 reached 36,781 units with an increase of $8.16 \%$, that number was around 5 percent of the population and most of the number of MSMEs was dominated by businesses in the micro sector especially food. This should show a significant contribution. However, the large number of SMEs is less productive and still lacks quality or creativity. In this case, SMEs have several obstacles, one of which is not yet preparing financial reports and preparing financial reports but not in accordance with generally accepted accounting standards in Indonesia, namely SAK EMKM. The weaknesses of SMEs in the preparation of financial statements are partly due to the low education and lack of understanding of Financial Accounting Standards (SAK), especially SAK EMKM.

This problem is caused by the fact that they feel difficulties in preparing financial reports even though in a simple form, whereas according to the regulations that have been issued, since January 1, 2018 MSMEs should prepare financial reports for each period.

This Community Service activity was held on August 3, 2019 and was attended by 28 participants of SME entrepreneurs in the city of Banjarmasin. The method used is training by providing material on the preparation of financial statements and the practice I practice of preparing financial statements in the case of Accounting for SME Brownies based on SAK EMKM. As a result of this activity, most participants have adequate understanding of simple accounting records.
\end{abstract}

Keywords: Financial Statements, SAK EMKM, UMKM Food.

\begin{abstract}
ABSTRAK
Jumlah UMKM di Banjarmasin pada tahun 2016 mencapai 33.781 unit dan tahun 2017 mencapai 36.781 unit dengan peningkatan 8,16\%, jumlah itu sekitar 5 persen dari penduduk dan sebagian besar dari jumlah UMKM didominasi oleh usaha pada sektor mikro khususnya pangan. Hal ini seharusnya menunjukkan kontribusi yang cukup besar. Namun jumlah UKM yang cukup besar tersebut kurang produktif dan masih kurang dari segi kualitas atau kreativitas. Dalam hal ini UMKM mempunyai beberapa kendala, salah satunya ialah belum menyusun laporan keuangan dan menyusun laporan keuangan namun belum sesuai standar akuntansi di Indonesia yang berlaku umum yaitu SAK EMKM. Kelemahan UKM dalam penyusunan laporan keuangan itu antara lain disebabkan rendahnya pendidikan dan kurangnya pemahaman terhadap Standar Akuntansi Keuangan (SAK) khususnya SAK EMKM.
\end{abstract}


Permasalahan ini disebabkan oleh karena mereka merasa kesulitan dalam menyusun laporan keuangan meskipun dalam bentuk sederhana, padahal menurut peraturan yang telah dikeluarkan, sejak 1 Januari 2018 UMKM seharusnya membuat laporan keuangan pada setiap periode.

Kegiatan Pengabdian kepada Masyarakat ini telah dilaksanakan pada tanggal 3 Agustus 2019 dengan dihadiri oleh 28 orang peserta pengusaha UMKM di Kota Banjarmasin. Metode yang dilakukan adalah pelatihan dengan memberikan materi tentang penyusunan laporan keuangan serta latihan/praktik penyusunan laporan keuangan berupa kasus Akuntansi UKM Brownies berdasarkan SAK EMKM. Hasil dari kegiatan ini, sebagian besar peserta memiliki pemahaman yang memadai mengenai pencatatan Akuntansi sederhana.

Kata Kunci: Laporan Keuangan, SAK EMKM, UMKM Pangan.

\section{PENDAHULUAN}

Berdasarkan data terakhir Dinas Koperasi dan UKM Kota Banjarmasin jumlah UMKM di kota Banjarmasin pada tahun 2016 mencapai 33.781 unit dan tahun 2017 mencapai 36.781 unit dengan peningkatan 8,16\% (Rakornas Dinas Koperasi dan UKM, 2018), jumlah itu sekitar 5 persen dari penduduk dan sebagian besar dari jumlah UMKM didominasi oleh usaha pada sektor mikro pangan. Hal ini seharusnya menunjukkan kontribusi yang cukup besar diberikan oleh entitas mikro terutama dalam membantu pemerintah untuk penanggulangan masalah kemiskinan dengan menyediakan lapangan pekerjaan baru dan menjadi salah satu sumber pemasukan pemerintah melalui pembayaran pajak. Namun berdasarkan catatan Dinas Koperasi dan UKM Kota Banjarmasin jumlah UKM yang cukup besar tersebut kurang produktif dan masih kurang dari segi kualitas atau kreativitas.

Dalam perkembangannya, UMKM mempunyai beberapa kendala. Salah satunya ialah belum menyusun laporan keuangan dan menyusun laporan keuangan namun belum sesuai standar akuntansi di Indonesia yang berlaku umum. Sebelumnya, DSAK IAI telah menerbitkan SAK ETAP untuk pedoman laporan keuangan UMKM. Akan tetapi pada praktiknya penerapan SAK ETAP pada UMKM memberikan hasil bahwa mayoritas UMKM belum menerapkan SAK ETAP. Hal tersebut dikarenakan oleh sebagian UMKM SAK ETAP diangap rumit. SAK EMKM dirancang sebagai standar akuntansi yang sederhana yang dapat digunakan untuk entitas mikro kecil dan menengah, sehingga UMKM dapat menyusun laporan keuangan untuk tujuan akuntabilitas dan pengambilan keputusan. Laporan keuangan tersebut dapat juga digunakan oleh entitas untuk memperoleh pendanaan dari pihak lain serta lampiran pelaporan pajak.

Kemudian DSAK IAI menerbitkan SAK EMKM pada tanggal 8 Desember 2016 dengan konsep yang lebih sederhana dibandingkan dengan SAK ETAP, ditujukan untuk digunakan oleh entitas yang tidak atau belum mampu memenuhi persyaratan akuntansi yang diatur dalam SAK ETAP dan diterbitkan untuk 
membantu UMKM memenuhi kebutuhan pelaporan keuangannya yang akan berlaku efektif pada tanggal 1 Januari 2018. SAK EMKM merupakan suatu sistem baru yang diterapkan pada usaha kecil dan menengah untuk mengoptimalisasi kinerja dan kualitas UMKM. Sebuah sistem baru biasanya akan dianggap rumit dan tidak akan sering digunakan oleh penggunanya apa lagi rata-rata pelaku usaha UMKM dari masyarakat yang bukan dari akuntansi dan tidak memahami bagaimana menyusun laporan keuangan berdasarkan standar yang berlaku umum. Masalah utama yang menjadi fokus dalam pengembangan UMKM adalah mengenai pengelolaan laporan keuangan berdasarkan standar yang telah ditetapkan yaitu SAK EMKM.

Sesuai dengan perkembangan UMKM dalam melaporkan laporan keuangannya, setelah dikeluarkan Standar Akuntansi Keuangan Entitas Mikro Kecil Menengah (SAK EMKM), diharapkan dapat memberi gambaran kinerja manajemen UMKM di masa lalu dan prospek di masa depan. Sehingga laporan keuangan yang dihasilkan dapat dipercaya dan diandalkan baik oleh pengurus maupun oleh anggota UMKM dan pihak eksternal yang memiliki kepentingan lain yang berhubungan dengan UMKM.

Mitra dalam pengabdian kepada masyarakat ini yaitu kelompok UMKM Pangan Kota Banjarmasin. Alasan memilih mitra karena menurut data dari Dinas Koperasi dan UKM Kota Banjarmasin jumlah UMKM di Banjarmasin dalam tahun 2016 mencapai 36 ribu unit dan didominasi oleh usaha pada sektor mikro pangan. Alasan lain memilih mitra karena selama ini mitra telah menjalin hubungan baik dengan Program Studi D3 Akuntansi melalui kegiatan pengabdian kepada masyarakat sebelumnya. Kondisi mitra saat ini yaitu belum memiliki kesadaran akan pentingnya penyusunan laporan keuangan. Kesadaran tersebut belum tumbuh karena mereka merasa kesulitan dalam menyusun Laporan Keuangan, faktor pendidikan juga menjadi sebab kurangnya pemahaman terkait akuntansi.

Melalui kegiatan pengabdian kepada masyarakat dengan judul "Pelatihan Penyusunan Laporan Keuangan Berdasarkan SAK EMKM pada UMKM Pangan di Kota Banjarmasin" diharapkan mampu menjadi solusi atas permasalahan UMKM Pangan yang belum bisa menyusun laporan keuangan berdasarkan Standar Akuntansi berlaku umum.

\section{PERMASALAHAN MITRA}

Berdasarkan pengamatan dan catatan Dinas Koperasi dan UKM Kota Banjarmasin serta observasi singkat kepada mitra, permasalahan yang dialami oleh mitra (UMKM Pangan) yaitu:

1. Kesulitan dalam menghitung omset penjualan;

2. Kesulitan dalam menghitung profit atau laba pada periode tertentu;

3. Sebagian UMKM Pangan mengalami kerugian dalam kegiatan operasionalnya; 
4. Kesulitan dalam pengajuan pinjaman atau kredit karena tidak mempunyai laporan keuangan.

Permasalahan di atas disebabkan karena UMKM Pangan belum menyusun laporan keuangan secara berkala. Sebagian besar dari mereka hanya mempunyai catatan kas masuk dan kas keluar yang sangat sederhana dan tentunya belum sesuai dengan Standar Akuntansi yang berlaku umum.

\section{TUJUAN DAN MANFAAT KEGIATAN}

Adapun tujuan dan manfaat dari kegiatan Pengabdian kepada Masyarakat ini yaitu:

1. Meningkatkan kesadaran dan memberikan pemahaman pada UMKM tentang pentingnya membuat atau menyusun laporan keuangan

2. berdasarkan Standar Akuntansi yang berlaku umum.

3. Memberikan pemahaman pada UMKM tentang manfaat dan kegunaan dari membuat atau menyusun laporan keuangan berdasarkan Standar Akuntansi yang berlaku umum.

4. Memberikan pelatihan tentang penyusunan laporan keuangan berdasarkan SAK EMKM.

\section{METODE KEGIATAN}

Metode pelaksanaan pengabdian kepada masyarakat ini yaitu dengan memberikan materi terkait Standar Akuntansi Keuangan (SAK) Entitas Mikro Kecil dan Menengah (EMKM) yang disampaikan oleh Bapak Sirajudin, SE, MSA, Ak, CA. Kemudian dilanjutkan dengan latihan kasus berupa kasus Akuntansi untuk UKM Pangan usaha Brownies yang disampaikan dan dipandu oleh bapak Mahyuni, SE, MM, Ak, CA. Seluruh peserta mengerjakan kasus di komputer dengan bantuan program Ms. Excel yang sudah disetting sedemikian rupa oleh pemateri. Saat latihan kasus, dosen-dosen Prodi D3 Akuntansi menjadi pendamping bagi peserta kegiatan.

Kegiatan pengabdian kepada masyarakat ini juga melibatkan peran mahasiswa. Adapun mahasiswa yang terlibat yaitu:

1. Sahri Mardini dari kelas 5A Prodi D3Akuntansi

2. Noor Aminuddin dari kelas 5A Prodi D3Akuntansi

3. Rina dari kelas 2B Prodi D3Akuntansi

4. Henny Ulfah dari kelas 2B Prodi D3Akuntansi 


\section{HASIL DAN PEMBAHASAN}

Kegiatan pengabdian kepada masyarakat, berupa pelatihan penyusunan laporan keuangan berdasarkan SAK EMKM pada UMKM pangan di Kota Banjarmasin ini, dilaksanakan pada hari Sabtu, tanggal 3 Agustus 2019, bertempat di ruang Laboratorium Komputer 1 Jurusan Akuntansi Politeknik Negeri Banjarmasin.

Pelatihan penyusunan laporan keuangan berdasarkan SAK EMKM pada UMKM pangan di Kota Banjarmasin dihadiri oleh pengusaha yang tergabung dalam HIPMIKINDO Banjarmasin sebanyak 28 orang. Kegiatan ini juga dihadiri oleh dosen dari Program Studi D3 Akuntansi Politeknik Negeri Banjarmasin.

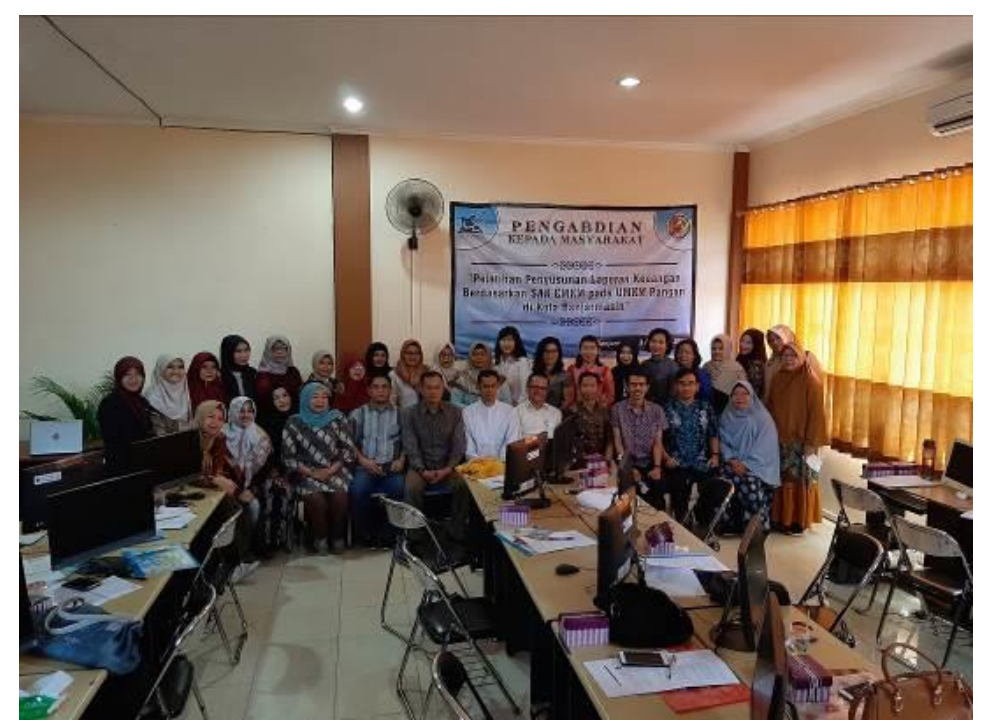

Gambar 1: Foto bersama seluruh peserta

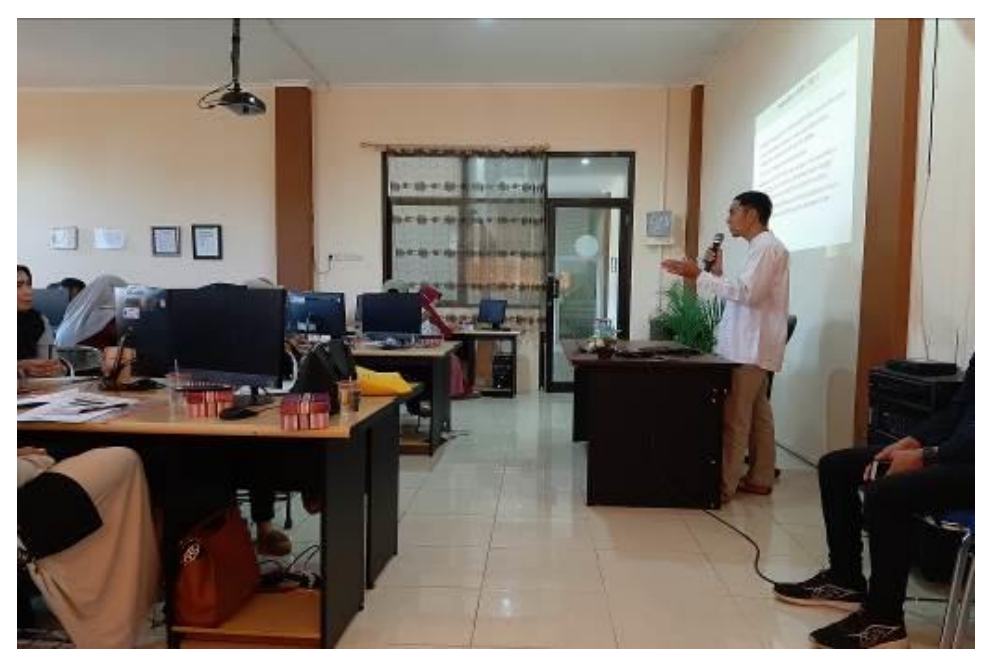

Gambar 2: Pemateri menyampaikan materi kepada peserta 


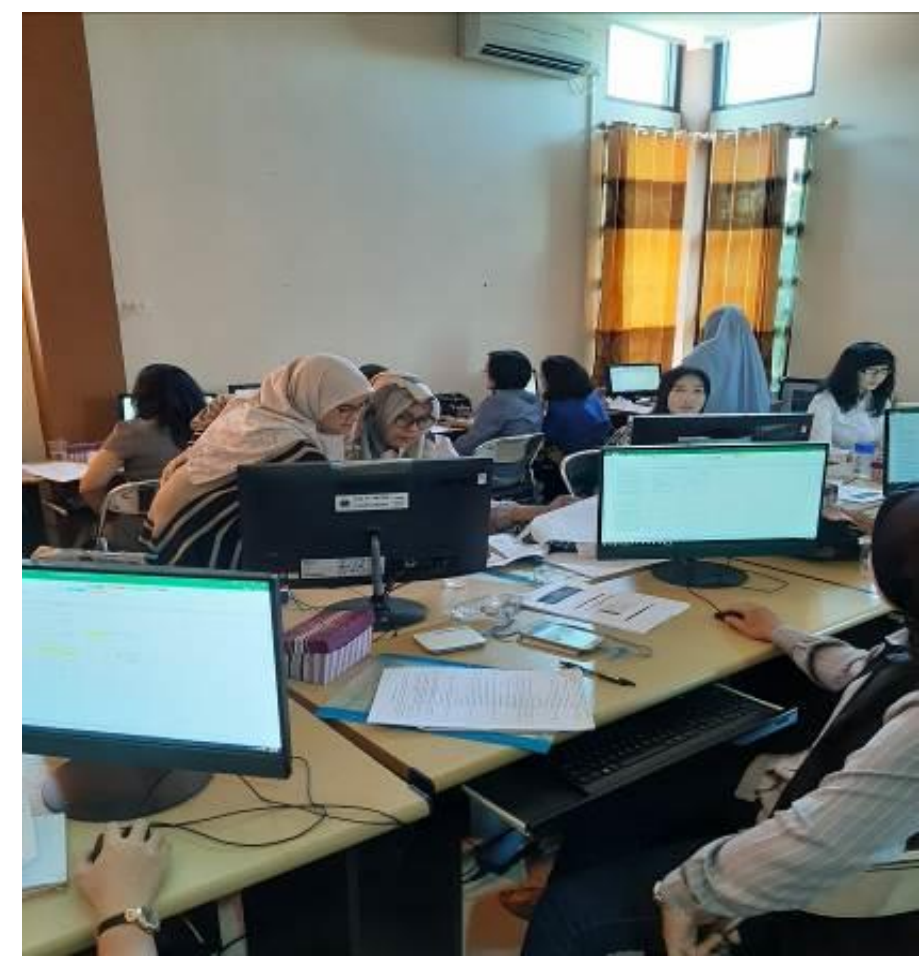

Gambar 3: Salah seorang dosen mendampingi peserta mengerjakan kasus

\section{KESIMPULAN DAN SARAN}

Kesimpulan dari kegiatan Pengabdian kepada Masyarakat ini yaitu:

1. Kegiatan Pengabdian kepada Masyarakat yang mengangkat tema Pelaporan Keuangan berdasarkan SAK EMKM telah dilaksanakan pada hari Sabtu tanggal 3 Agustus 2019 di Jurusan Akuntansi dengan melibatkan peserta dari pengusaha HIPMIKINDO Banjarmasin.

2. Peserta mendapatkan materi berupa Pelaporan Keuangan berdasarkan SAK EMKM dan juga mendapatkan bimbingan dalam mengerjakan kasus Akuntansi UKM sebagai bentuk latihan atas materi yang telah didapat.

Adapun saran dari kegiatan Pengabdian kepada Masyarakat ini yaitu HIPMIKINDO dan Prodi D3 Akuntansi dapat menjalin kerjasama lebih lanjut agar ke depan dapat terus saling bersinergi dalam kegiatan-kegiatan lainnya.

\section{DAFTAR PUSTAKA}

Dinas Koperasi dan UKM Kalimantan Selatan, 2018. Rakornas Bidang KUMKM, Yogyakarta. 